\title{
Character Association and Path Co-Efficient Analysis Studies for Yield and its Contributing Traits in Groundnut (Arachis hypogaea L.)
}

\author{
R. S. Ganvit ${ }^{*}$ and P. K. Jagtap \\ Department of Genetics and Plant Breeding and Niger Research Station, Vanarasi, Navsari \\ Agricultural University, Navsari, Gujarat, India \\ *Corresponding author
}

A B S T R A C T

\section{Keywords \\ Correlation coefficient, Association, Direct and Indirect effects, cleistogamous, \\ Groundnut}

Article Info

Accepted:

25 October 2018

Available Online:

10 November 2018
Correlation studies revealed that the genotypic correlations were higher than their corresponding phenotypic correlation for all the characters and the depended trait pod yield per plant was significantly and positively correlated at both phenotypic and genotypic levels with number of mature pods per plant, kernel yield per plant, shelling percent and days to 50\% flowering.Path coefficient analysis revealed that kernel yield per plant, number of mature pods per plant exhibited high and positive direct effects on pod yield per plant. Whereas, 100 kernel weight, plant height, days to $50 \%$ flowering exhibited low and positive direct effects towards pod yield.These findings suggested that emphasis should be given on these traits for selecting elite genotypes and further breeding programme.

\section{Introduction}

Groundnut is an allotetraploid $(2 n=4 x=40)$ with a basic chromosome number of $\mathrm{x}=10$ and it is highly self-pollinated crop having cleistogamous flowers. Groundnut is an unpredictable crop due to its underground pods development. It is an annual legume with high quality edible oil and easily digestible protein of its kernels. Pod yield is not only polygenically controlled, but also influenced by its component characters. Direct selection of pod yield would not be reliable approach without giving due importance to its genetic nature, owing to its complex nature of inheritance. Information on phenotypic and genotypic interrelationship of pod yield with its components characters and also among the characters themselves would be very much useful to the plant breeder in developing an appropriate breeding strategy.

But, the correlations give information about the component traits, they do not provide a true picture of relative importance of direct and indirect effects of these component traits on pod yield. Hence, the path coefficient analysis permits the separation of direct effects from indirect effects and gives more realistic relationship of the characters and help in effective selection. Therefore, the present study on Spanish bunch genotypes was 
conducted to study the correlation and path coefficients.

\section{Materials and Methods}

The experimental material consisted fourty genotypes of groundnut were sown in a Randomized Block Design with three replications during Summer 2015-16. The present investigation was carried out at Research Farm of Niger Research Station, Navsari Agricultural University, Vanarasi, Tal- Vansda, Dist-Navsari. Each entry was accommodated in a single row of $3.0 \mathrm{~m}$ length with a spacing of $45 \times 15 \mathrm{~cm}$. The experiment was surrounded by two guard rows to avoid damage and border effects. The recommended agronomical practices and plant protection measures were followed for the successful raising of the crop witheight irrigations throughout crop period.

The observations were recorded on five randomly selected plants in each entry and replication for ten characters viz., day to $50 \%$ flowering, day to maturity, plant height, number of mature pods per plant, pod yield per plant, kernel yield per plant, 100- pod weight, 100- kernel weight, shelling percentage and oil content (oil content was determined by automatic soxhlet extractor as suggested by Franz von Soxhlet) and their mean values were used for the statistical analysis. The phenotypic and genotypic correlation coefficients of all the characters were worked-out as per Al-Jibouri et al., (1958) andthe path coefficient analysis was carried-out as per the method suggested by Dewey and Lu (1959).

\section{Results and Discussion}

The study of genotypic correlation gives an idea of the extent of relationship between different variables. This relationship among yield contributing characters as well as their association with pod yield provides information for exercising selection pressure for bringing genetic improvement in pod yield. In general, the values of genotypic correlations were higher than their corresponding phenotypic correlations.

This indicated that though there was high degree of association between two variables at genotypic level, its phenotypic expression was deflated by the influence of environment. It has also indicated that there was an inherent relationship between the characters studied which is in agreement with the conclusions of Dolma et al., (2010) and Zaman et al., (2011).

The pod yield per plant had highly significant and positive correlations at both genotypic and phenotypic levels with number of mature pods per plant ( $\mathrm{rg}=0.874, \mathrm{rp}=0.780)$, kernel yield per plant $(\mathrm{rg}=0.986, \quad \mathrm{rp}=0.961)$, shelling percent $(\mathrm{rg}=0.892, \mathrm{rp}=0.790)$ and days to $50 \%$ flowering ( $\mathrm{rg}=0.306, \mathrm{rp}=0.242)$, while oil content ( $\mathrm{rg}=0.233$ ) had significant but very poor association at genotypic level and also positive and non-significant correlation at phenotypic level.

Plant height ( $\mathrm{rg}=-0.177, \mathrm{rp}=-0.176)$, days to maturity (rg=-0.146, $\mathrm{rp}=-0.070)$ and $100 \mathrm{pod}$ yield ( $\mathrm{rg}=-0.051, \mathrm{rp}=-0.034)$ had negative and non-significant correlation at both genotypic and phenotypic levels. 100 kernel yield ( $\mathrm{rg}=0.061, \mathrm{rp}=0.045)$ had positive and nonsignificant correlation at both genotypic and phenotypic levels with pod yield per plant.

The positive genotypic association has been reported between pod yield per plant and number of mature pods per plant by Bhosale $e t$ al., (2011); Gupta et al., (2015); Patil et al., (2015); Vasanthi et al., (2016) and Prabhu et al., (2017), for kernel yield per plant by Meta and Monpara, (2010) and for shelling out-turn by Bhosale et al., (2011) and Gupta et al., (2015). 


\section{Int.J.Curr.Microbiol.App.Sci (2018) 7(11): 3566-3572}

Table.1 Genotypic $\left(r_{g}\right)$ and Phenotypic $\left(r_{p}\right)$ correlation among ten characters in fourty genotypes of groundnut

\begin{tabular}{|c|c|c|c|c|c|c|c|c|c|c|}
\hline Characters & & Days to maturity & Plant height (cm) & No. of mature pods/plant & $\begin{array}{c}\text { Kernel yield/plant } \\
(\mathrm{g})\end{array}$ & $\begin{array}{c}100 \\
\text { pod weight } \\
\text { (g) }\end{array}$ & $\begin{array}{c}100 \\
\text { kernel weight } \\
(\mathrm{g})\end{array}$ & Shelling (\%) & Oil content (\%) & $\begin{array}{l}\text { Pod yield } \\
\text { per plant } \\
\text { (g) }\end{array}$ \\
\hline \multirow{2}{*}{$\begin{array}{l}\text { Days to } 50 \% \\
\text { flowering }\end{array}$} & $r_{g}$ & 0.086 & 0.060 & $0.222^{*}$ & $0.288 * *$ & 0.024 & -0.143 & $0.254^{* *}$ & 0.001 & $0.306^{* *}$ \\
\hline & $r_{p}$ & 0.048 & 0.067 & $0.183^{*}$ & $0.240^{* * *}$ & -0.005 & -0.109 & $0.223^{*}$ & 0.003 & $0.242 * *$ \\
\hline \multirow[t]{2}{*}{ Days to maturity } & $\mathrm{r}_{\mathrm{g}}$ & & $0.272 * *$ & 0.062 & $-0.182^{*}$ & -0.024 & -0.076 & $-0.232 * *$ & $-0.214^{*}$ & -0.146 \\
\hline & $\mathrm{r}_{\mathrm{p}}$ & & 0.104 & -0.022 & -0.098 & -0.005 & -0.019 & -0.098 & -0.089 & -0.070 \\
\hline \multirow[t]{2}{*}{ Plant height (cm) } & $\mathrm{r}_{\mathrm{g}}$ & & & $-0.254 * *$ & $-0.183^{*}$ & -0.081 & 0.178 & -0.128 & -0.007 & -0.177 \\
\hline & $\mathrm{r}_{\mathrm{p}}$ & & & $-0.205^{*}$ & $-0.179 *$ & -0.081 & 0.015 & -0.124 & 0.024 & -0.176 \\
\hline \multirow{2}{*}{$\begin{array}{l}\text { No. of mature pods } \\
\text { per plant }\end{array}$} & $r_{g}$ & & & & $0.821 * *$ & 0.061 & -0.099 & $0.693^{* *}$ & $0.252^{* *}$ & $0.874 * *$ \\
\hline & $r_{p}$ & & & & $0.737 * *$ & 0.046 & -0.117 & $0.592 * *$ & 0.177 & $0.780 * *$ \\
\hline \multirow{2}{*}{$\begin{array}{c}\text { Kernel yield/plant } \\
\text { (g) }\end{array}$} & $\mathrm{r}_{\mathrm{g}}$ & & & & & -0.021 & -0.015 & $0.949^{* *}$ & $0.194^{*}$ & $0.986^{* *}$ \\
\hline & $r_{p}$ & & & & & -0.011 & -0.017 & $0.903^{* *}$ & 0.140 & $0.961^{* *}$ \\
\hline \multirow[t]{2}{*}{ 100-pod weight (g) } & $r_{g}$ & & & & & & $0.249 * *$ & 0.039 & $0.211^{*}$ & -0.051 \\
\hline & $r_{p}$ & & & & & & $0.222^{*}$ & 0.038 & 0.169 & -0.034 \\
\hline \multirow{2}{*}{$\begin{array}{l}\text { 100-kernel weight } \\
(\mathrm{g})\end{array}$} & $\mathrm{r}_{\mathrm{g}}$ & & & & & & & -0.115 & $0.363^{* *}$ & 0.061 \\
\hline & $r_{p}$ & & & & & & & -0.100 & $0.286^{* *}$ & 0.045 \\
\hline \multirow[t]{2}{*}{ Shelling (\%) } & $\mathrm{r}_{\mathrm{g}}$ & & & & & & & & 0.100 & $0.892 * *$ \\
\hline & $r_{p}$ & & & & & & & & 0.085 & $0.790 * *$ \\
\hline \multirow[t]{2}{*}{ Oil content (\%) } & $\mathrm{r}_{\mathrm{g}}$ & & & & & & & & & $0.233^{*}$ \\
\hline & $r_{p}$ & & & & & & & & & 0.143 \\
\hline
\end{tabular}


Table.2 Genotypic path coefficient analysis showing direct (diagonal and bold) and indirect effects of different charecters on pod yield of groundnut genotypes

\begin{tabular}{|c|c|c|c|c|c|c|c|c|c|c|}
\hline Characters & $\begin{array}{l}\text { Days to } \\
\mathbf{5 0 \%} \\
\text { flowering }\end{array}$ & $\begin{array}{l}\text { Days to } \\
\text { maturity }\end{array}$ & $\begin{array}{l}\text { Plant } \\
\text { height } \\
\text { (cm) }\end{array}$ & $\begin{array}{c}\text { No. of } \\
\text { mature } \\
\text { pods per } \\
\text { plant }\end{array}$ & $\begin{array}{c}\text { Kernel } \\
\text { yield/plant } \\
\text { (g) }\end{array}$ & $\begin{array}{l}100 \text { pod } \\
\text { weight } \\
\text { (g) }\end{array}$ & $\begin{array}{l}100 \text { kernel } \\
\text { weight (g) }\end{array}$ & $\begin{array}{l}\text { Shelling } \\
(\%)\end{array}$ & $\begin{array}{c}\text { Oil } \\
\text { content } \\
(\%)\end{array}$ & $\begin{array}{c}\text { Genotypic } \\
\text { correlation } \\
\text { with pod } \\
\text { yield/plant }\end{array}$ \\
\hline Days to $50 \%$ flowering & 0.0497 & 0.0043 & 0.0030 & 0.0110 & $0 . .0143$ & 0.0012 & -0.0071 & 0.0126 & 0.0000 & $0.3056^{* *}$ \\
\hline Days to maturity & -0.0030 & -0.0342 & -0.0093 & -0.0021 & 0.0062 & 0.0008 & 0.0026 & 0.0079 & 0.0073 & -0.1464 \\
\hline Plant height (cm) & 0.0006 & 0.0027 & 0.0100 & -0.0026 & -0.0018 & -0.0008 & 0.0018 & -0.0013 & -0.0001 & -0.1772 \\
\hline $\begin{array}{l}\text { No. of mature pods per } \\
\text { plant }\end{array}$ & 0.0586 & 0.0165 & -0.0671 & 0.2639 & 0.2166 & 0.0162 & -0.0263 & 0.1828 & 0.0666 & $0.8743 * *$ \\
\hline $\begin{array}{l}\text { Kernel yield per plant } \\
\text { (g) }\end{array}$ & 0.2374 & -0.1501 & -0.1509 & 0.6771 & 0.8251 & -0.0175 & -0.0124 & 0.7827 & 0.1604 & $0.9860 * *$ \\
\hline 100 pod weight (g) & -0.0018 & 0.0017 & 0.0060 & -0.0046 & 0.0016 & -0.0743 & -0.0185 & -0.0029 & -0.0157 & -0.0519 \\
\hline 100 kernel weight (g) & -0.0173 & -0.0091 & 0.0215 & -0.0120 & -0.0018 & 0.0301 & 0.1207 & -0.0138 & 0.0438 & 0.0611 \\
\hline Shelling (\%) & -0.0187 & 0.0171 & 0.0094 & -0.0510 & -0.0698 & -0.0028 & 0.0084 & -0.0736 & -0.0074 & $0.8924 * *$ \\
\hline Oil content $(\%)$ & 0.0000 & 0.0047 & 0.0001 & -0.0056 & -0.0043 & -0.0047 & -0.0080 & -0.0022 & -0.0220 & $0.2330 *$ \\
\hline
\end{tabular}

*,** Significant at $5 \%$ and $1 \%$ levels, respectively

Residual effect, $R=0.0031$, N.B.: Values at diagonal indicate direct effects of respective character 
The days to $50 \%$ flowering which had highly significant and positive association with number of mature pods per plant and kernel yield per plant at both genotypic and phenotypic levels while day to maturity had non- significant and negative association (Kumar et al., 2014) is an important component in identifying and deciding the duration of the crop.

Thus, on the basis of correlations, number of mature pods per plant, kernel yield per plant, day to $50 \%$ flowering and shelling out-turn were proved to be the outstanding characters influencing pod yield in groundnut and they can serve as marker indicator characters for improvement in pod yield and need to be given importance in selection to achieve higher pod yield.

The path coefficient analysis revealed that the number of mature pods per plant and kernel yield per plant exhibited high and positive direct effects on pod yield per plant. Thus, these characters turned-out to be the major components of pod yield and direct selection for these traits will be rewarding for yield improvement. Similar reported by Raut et al., (2010), Vekariya et al., (2010). The character like days to $50 \%$ flowering, 100 kernel weight and plant height exhibited low and positive direct effects with pod yield per plant. While, days to maturity (Patel and Shelke 1992), 100 pod weights, shelling percent and oil content had low and negative direct effect towards pod yield per plant. The kernel yield per plant traits exhibited positive indirect effects via days to $50 \%$ flowering, number of mature pods per plant, shelling percent and oil content. Shelling percent had negative indirect effect on pod yield per plant via days to $50 \%$ flowering, number of mature pods per plant, kernel yield per plant, 100 pod weight and oil content. Oil content also had negative indirect effect on pod yield per plant via number of mature pods per plant, kernel yield per plant, 100 pod weight, 100 kernel weight and shelling percent whereas remaining characters viz., days to maturity and plant height had negligible and positive indirect effects on pod yield per plant. This finding are in accordance with Raghuvansi et al., (2015); Bhargavi et al., (2017); Ram et al., (2017).

It was clear from the path analysis that the maximum direct effects as well as appreciable indirect influences were exerted by number of mature pods per plant, kernel yield per plant, shelling percent, oil content and day to $50 \%$ flowering. These characters also exhibited highly significant and positive associations with pod yield per plant and hence, they may be considered as the most important yield contributing characters and due emphasis should be placed on these components while selecting for high yielding types in groundnut.

From the above discussion, it is clear that pod yield per plant was found to be significantly and positively correlated with number of mature pods per plant, kernel yield per plant, shelling percent and days to $50 \%$ flowering at genotypic and phenotypic levels while path coefficient analysis showed kernel yield per plant, number of mature pods per plant exhibited high and positive direct effects on pod yield per plant and also 100 kernel weight, plant height, days to $50 \%$ flowering exhibited low but positive direct effects towards pod yield. Hence, these traits were considered as the most important yield contributors and due emphasis should be given while attempting pod yield improvement in groundnut.

\section{References}

Al-Jibouri, H. A.; Miller, P. A. and Robinson, H. F. (1958). Genotypic and environmental variances in upland cotton cross of interspecific origin. Agron. J., 50: 633-635.

Bhargavi, G.V., Satyanarayana R., Ratna, D.B. and Narasimha K.L. (2017). Character 
association and path coefficient analysis of pod yield and yield components in spanish bunch Groundnut (Arachis hypogaea L.), Ele. J. Pl. Breed., 6(3): 764-770.

Bhosale, S. D. (2011). Character association, selection indices and genetic divergence in groundnut (Arachis hypogaea L.). Unpublished M.Sc. (Agri.) thesis submitted to the Junagadh Agricultural University, Junagadh.

Dewey, D. R. and Lu, K. H. (1959). A correlation and path coefficient analysis of components of crested wheat grass seed production. Agron. J., 51: 511-518.

Dolma, T.; Sekhar, M. R. and Reddy, K. R. (2010). Genetic variability, correlation and path analysis for yield its components in late leaf spot resistance in groundnut (Arachis hypogaea L.). J. Oilseeds Res., 27(2): 154157.

Gupta, R. P.; Vachhani, J. H.; Kachhadia, V. H.; Vaddoria, $\quad M$. A. and Reddy, P. (2015).Genetic variability and heritability studies in Virginia groundnut (Arachis hypogaea L.).Electronic Journal of Plant Breeding, 6 (1): 253-256.

Kumar, C. P.; Rekha, R.; Venkateswarulu, O. and Vasanthi, R. P. (2014). Correlation and path coefficient analysis in groundnut (Arachis hypogaea L.). Inter. J. Appl. Bio. Pharma. Tech., 5 (1):8-11

Meta, H. R. and Monpara, B. A. (2010).Genetic variation and trait relationships in summer groundnut (Arachis hypogaea L.).J. Oilseeds Res., 27(1): 8-11.

Patel, M. P. and Shelke, V. B. (1992). Path analysis in pre- monsoon groundnut.GAU Res. J., 17: 79-81.

Patil, S.; Shivanna, S.; Irappa, B. M. and Shweta. (2015). Genetic variability and character association studies for yield and yield attributing components in groundnut (Arachis hypogeae L.).International Journal of Scientific Research. 6(6): 4568-4570.
Prabhu R., Manivannan N., Mothilal A. and Syed I.M. (2017). Variability, Correlation and Path Coefficient Analysis in Groundnut (Arachis hypogaea L.). Electronic Journal of Plant Breeding, 5(4): 824-827.

Ram, T. D.; Sharma, H.; Kumar, R. and Ram, K. (2017). Correlation and path analysis for yield and its contributing traits in groundnut (Arachis hypogaea L.). Intern. J. Agril. Sci., 9 (10): 3997-3999.

Raguvanshi, S. S.; Kachhadia, V. H.; Vachani, J. H.; Jivani, L. L.; Malav, A. K. and Indu, A. K. (2015). Character association and path analysis in groundnut (Arachis hypogaea L.). Electronic Journal of Plant Breeding, 10(3): 155-158.

Raut, R. D.; Dhaduk, L. K. and Vachhani, J. H. (2010). Character association and path coefficient analysis in $\mathrm{F}_{2}$ generation of groundnut (Arachis hypogaea L.). Int. J. of Agri. Sci., 6(1): 305-310.

Soxhlet*, F. (1879). "Die gewichtsanalytische Bestimmung des Milchfettes". Dingler's Polytechnisches Journal (in German). 232: 461-465.

Vasanthi, R. P.; Suneetha, N.; and Sudhakar, P. (2016). Genetic variability and correlation studies for morphological, yield and yield attributes in groundnut (Arachis hypogaea L.). Legume research, 38(1):9-15.

Vekariya, H. B.; Khanpara, M. D.; Vachhani, J. H.; Jivani, L. L.; Vagadiya, K. J. and Revar, H. J. (2010). Correlation and path analysis in bunch groundnut (Arachis hypogaea L.). Intl. J. Plant Sci., 6(1): 11-15.

Zaman, M. A.; Tuhina, K. M.; Ullah, M. Z.; Moniruzzamn, M. and Alam, K. H. (2011). Genetic variability and path analysis of groundnut (Arachis hypogaea L.). A Scientific Journal of Krishi Foundation the Agriculturists, 9(1\&2): 29-36.

\section{How to cite this article:}

Ganvit R. S. and Jagtap P. K. 2018. Character Association and Path Co-Efficient Analysis Studies for Yield and Its Contributing Traits in Groundnut (Arachis hypogaea L.). Int.J.Curr.Microbiol.App.Sci. 7(11): 3566-3572. doi: https://doi.org/10.20546/ijcmas.2018.711.409 